\title{
21] 末梢静脈輸液の輸液圧について
}

小林 勝 (精神医学研究所 $M E$ 室) 小方 卓 (東京武蔵野病院外科)

輸液ポンプによる末梢静脈輸液に於いて，輸液針に 加わる压力（輸液圧と呼ぶ）は, 輸液針の圧力損失, 末梢静脈圧，呿よび輸液点とポンプの高低差による压 の総和である．輸夜圧は輸液ポンプの負荷である輸夜 の状態を反映する重要な情報源であると考える。しか し, 現在多くの輸液ポンプでは, 閉塞が起こると輸液 圧が上昇し, ポンプの最大圧に達すると, 閉塞アラー ムを鳴らし停止させるだけで㐫る。最大圧では輪液セ ットに多量の液が貯留され，処置を誤るとボーラスを 起こす事になる．異常な輸夜の状態をいち早く検出す る為には, 輸夜圧に含まれる情報を解析して㧍く必要 がある，我々は，輸液針の圧力損失の測定と，輸液中 の末梢静脈圧の測定を行ない，輸夜圧について考察を 加光報告する。

輸液針の圧力損失の測定 : 圧力雑音の少ない輸夜ポ ンプを選び，その輸夜セットの先端に圧カセンサー及 び測定対象の輸夜針を付けた三方活栓を接続し，輸液
解析装置に接続する.ポンプの流量を $1 \sim 300 \mathrm{ml} / \mathrm{h}$ の籁团で設定し, ポンプの 1 サイクル以上の時間運転 させた正常な輸液プロフィルから平均圧力と平均流量 を算出し記録する. 1 本の輸夜針について 5 種類の流 量に於ける平均圧力と平均流量をプロットして圧力損 失一流量特性のグラフを得る. 測定対象は, 静脈針, 静脈カテーテルである.

末梢静脈圧の測定 : この実験の目的を理解し, 協力 してくれる人を対象として, 未梢静脈輸液中の輸液圧 を測定した．輸液点は手首の橈側皮静脈とし，22Gの 静脈カテーテルを刺入した. カテーテルと輸夜セット を接続し，さらにポンプと同じ高さに圧トランスデュ 一サを付けた三方活栓で輸液セットとポンプを接続し た. $10 \mathrm{ml} / \mathrm{h}$ の流量で生理食塩水を輸液し, 被験者に 色々な姿勢を試みさせ，輸夜圧の变動を観察した。こ れらの輸液圧から，輸夜針の圧力損失を差し引いた値 が末梢静脈圧である.

\section{2]血液透析施設での Ion Selective Electrode (ISE) を用いた電解質測定の 有用性亡イオン化カルシゥム值の意義について}

高橋雅彦，小笠原陽（小笠原クリニック）芝本 隆（東京医科歯科大腎臓センター）

[目的〕血液透析療法の目的から透析液電解質濃度 は患者の最適条件汇リアルタイムに設定変更する必要 がある. 従って，透析現場では電解質分析装置が必須 となる. ISE 法 ( $\mathrm{Na}, \mathrm{K}, \mathrm{Ca}$ 測定) と炎光法 ( $\mathrm{Na}$, $\mathrm{K}$ 湘定）に上る電解質分析装置を使用し血液透析での 閊者の総合的部価を行なった。また，ISE 法でのイオ ン化カルシウム $(\mathrm{iCa})$ 測定の意義について検討した.

[万法]対象は慢珄㹂不全患者69名（M38 F 31） で平均年齢は 55.6 歳 $(27 \sim 80$ 藏) で方る。原疾患は 慢性糸球体腎炎, のら胞腎, 糖尿病性腎症, 他である. 検討項目は ISE 法の測定精密度は炎光法と比較する 事で行ない, iCa 值の測定意義は $\mathrm{pH}$ の変化との関係 から観察した、また，両測定方法の血液透析に括ける 使いやすさなどについても考察を加えた。測定検体は 標準血清 (CRS), 全血, 血清, 血墏を用い, ISE 法 には LYTENING-6 (アムデブ社), 炎光法には PKC -480（コーニング社）を使用した.

〔結果】 CRS の Na 值では ISE 法と䌘準值との 間汇良好な相関が得られ $(r=0.9810, n=30)$, 炎光
法も同様であった $(\mathrm{r}=0.9820, \mathrm{n}=30)$. また， $\mathrm{K}$ 值 も同様の成績が得られた. ISE 法の全血 $\mathrm{Na}$ 值と炎 光法の血漿 $\mathrm{Na}$ 值の間には, $\mathrm{r}=0.8412(\mathrm{n}=120)$ の 相関が得られ，K では $\mathrm{r}=0.9433$ であった. 透析液 $\mathrm{iCa}$ とH の関係は車者の間に負の相関が認められた が, 総 $\mathrm{Ca}$ と $\mathrm{pH}$ 間に相関は認められなかった。测 定時間は, ISE 法の検体採取から測定までの所用時間 は約20秒，炎光法は血清分離を含め20分であった。

〔結語】 ISE 法による $\mathrm{Na}, \mathrm{K}$ の测定伯は炎光法に よる測定値と良好な相関を認ぬ，CRS 標準值と測定 值との相関も良好であった. ISE 法による測定精密度 は従来よりの炎光法による測定值と比較した籁团では その测定佰は満足できる. ISE 法では全血による測定: が可能なため測定に要する時間は短く炎光法に比べ簡 便であった，従って，リアルタイムで血中や透析液中 の電解質情報を必要とする血液透析では，ISE 法分析 装置の有用性は高い, 透析患者では, 治療前後で $\mathrm{pH}$ が変化するため $\mathrm{iCa}$ 值が重要となる. 総 $\mathrm{Ca}$ 值では $\mathrm{pH}$ に関係なく值は一定となる。 